\title{
Panel calls for sea change to fisheries policy
}

Virginia Gewin, Portland

A heavyweight independent commission is calling for a drastic overhaul of US fisheries policy, and the creation of an independent government agency to manage the oceans surrounding the United States.

The Pew Oceans Commission, funded by the Pew Charitable Trusts and comprising 18 prominent environmentalists, scientists and officials from government and the fisheries industry, wants fisheries policy to be based explicitly on ecosystem management.

To prevent further harm from overfishing, ocean pollution and invasive species, the commission recommends the creation of an independent national oceans agency, the adoption of a national ocean-policy act, doubling of ocean research spending over 5 years, and the establishment of a network of national marine reserves, or protected areas.

But it remains to be seen whether the Pew commission's findings, to be released this week, will be endorsed by the governmentsponsored US Commission on Ocean Policy, chaired by James Watkins, when it issues its report in the autumn. The latter is expected to shape US ocean policy for years to come (see Nature 418, 718; 2002).

Leon Panetta, chair of the Pew commission and former White House chief of staff, says he is confident that Watkins' commission will reinforce his own findings. "I sat down with Watkins very early on and we decided that if the two commissions came out in different places it would undermine what we are trying to do," he says. The commission chairs have since testified

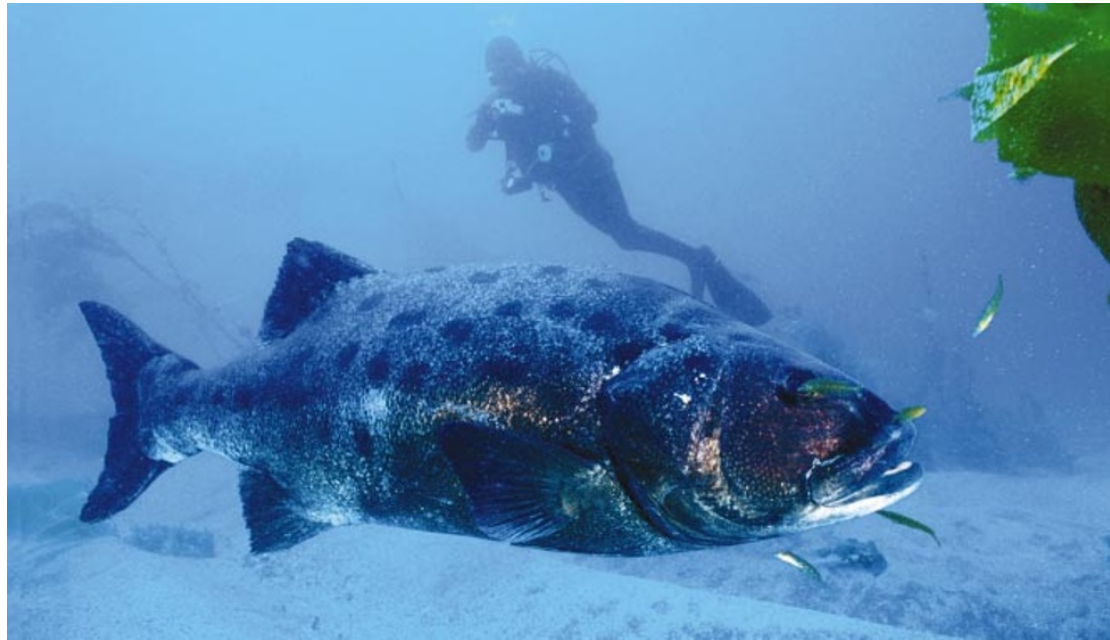

Net benefit? The Pew Oceans Commission wants an independent agency to manage ocean ecosystems.

before each other and held joint meetings.

Marine experts say the Pew commission's recommendations would help to streamline the convoluted array of agencies and budgetary committees that currently manage US oceans. Representative Sam Farr (Democrat, California), co-chair of the bipartisan House Oceans Caucus, lauds the report as "a handbook for what needs to be done". But he adds that real reform proposals would have to be led by the Bush administration - and that none are expected until after Watkins' commission releases its report.

"The administration is not notable for enthusiasm for green issues, but this is a blue issue," says Charles Kennel, a member of the

\section{Japanese team makes stem cells}

\section{David Cyranoski, Tokyo}

Japan has joined the club of countries that have produced their own human embryonic stem-cell lines.

Norio Nakatsuji and his group at Kyoto University announced on 27 May that their first stem cells had been successfully established and would be made available to other researchers in the autumn. The cells will be sold at cost to both academic and commercial researchers in Japan who have the government's permission to use them.

Under rules set in September 2001, researchers in Japan can conduct research on human embryonic stem cells, subject to approval by university and educationministry committees. The education ministry is still deciding how to handle requests for access to the cell lines from foreign laboratories.

According to Nakatsuji, about ten laboratories have already expressed an interest in the cell lines, and he expects 20-30 applications to use the cells by the end of the year.

His group plans to establish five more stem-cell lines for researchers. But difficulties in collecting frozen embryos which requires extensive informed-consent procedures - have slowed down the group's progress so far, one team member says.

Several research groups in Japan have been working with human embryonic stem cells bought from suppliers abroad, such as WiCell Research Institute at the University of Wisconsin in Madison, and Monash University near Melbourne, Australia. But unlike cells from these suppliers, those from Kyoto will not come with materialtransfer agreements claiming a share of the profits from any commercial products derived from the research.
Pew commission and director of the Scripps Institution of Oceanography in La Jolla, California. "The problem with the ocean is that it's nobody's backyard, it's a national resource."

The Pew commission calls for most of the ocean responsibilities of the National Oceanic and Atmospheric Administration (NOAA), as well as the ocean-related functions of other government agencies, to be transferred to a new ocean agency outside the Department of Commerce, of which NOAA is part.

But such reorganizations are notoriously hard to execute in Washington. And Bill Hogarth, deputy director of NOAA Fisheries, says that a revamp wouldn't make hard policy choices any easier.

The Pew commission's recommendation of ecosystem-based fisheries management may also prove contentious. "We haven't resolved what ecosystem-based management really means," cautions Hogarth. "Some people think it's just setting up marine protected areas."

Indeed, many marine biologists support such reserves. "If no such network of marine protected areas is implemented, there is no way that stocks aren't going to continue crashing," says Daniel Pauly, a fisheries biologist at the University of British Columbia in Vancouver, Canada.

The two commissions were established because of a widespread sense that US oceans policy was floundering. Thirty years after NOAA was created as a sort of Earthbound NASA, it has yet to match the space agency's budget or status.

Oceanographers admit that Washington's single-minded focus on terrorism makes it hard to draw attention to ocean issues. But Kennel points out that these issues aren't going to go away, and that this year's push for reform is the best chance to bring about badly needed change. 